\title{
CORPORATE GOVERNANCE IN SPANISH BANKS: 2011
}

\author{
Guido Stein \\ Javier Capape \\ Manuel Gallego
}




\title{
CORPORATE GOVERNANCE IN SPANISH BANKS: 2011
}

\author{
Guido Stein ${ }^{1}$ \\ Javier Capape ${ }^{2}$ \\ Manuel Gallego ${ }^{3}$
}

\section{Abstract}

Spanish laws and regulations on corporate governance operate within the framework of European laws and regulations and are based on the circulars issued by the Banco de España and the Recommendations of the Unified Code (2006).

In this study we have situated Spanish banks within the overall domain of corporate governance. Taking the ten largest banks by market capitalization, we have drawn a map, on which we have situated the banks according to their ownership and governance.

Although general models of governance based on geographical criteria (United States, British and European models) do exist, they are not exactly applicable to Spanish banks. On the one hand, Banco Santander and BBVA are closer in some respects to the United States or British conception of governance, with low shareholder concentration, high free float and a large presence of institutional investors. The boards of these banks have more independent directors than the average and the proportion of proprietary directors is small. As regards total directors' remuneration, it is worth noting that the figures for Santander and BBVA exceed the average for Ibex 35 companies by 400\% and 180\%, respectively.

A historical exception is Banco Popular, where a high percentage of the owners are represented directly on the board, and which has recently acquired Banco Pastor. Also, the salary of the chairman and two senior managers account for $80 \%$ of the total directors' remuneration, amounting to 1.8 million euros.

Keywords: corporate governance, banks, savings banks

Note: The authors would like to thank the collaboration of the dean and faculty of the Keio Business School for introducing us to the Japanese executives interviewed.

\footnotetext{
${ }^{1}$ Associate Professor, Managing People in Organizations, IESE

${ }^{2}$ Researcher at ESADEgeo

${ }^{3}$ Research Assistant at IESE
} 


\section{CORPORATE GOVERNANCE IN SPANISH BANKS: 2011}

\section{Introduction}

The financial industry in Spain is facing a period of radical change. After many years in which savings banks ("cajas") and banks coexisted, new capital requirements have sparked a massive concentration process, through mergers and acquisitions.

One of the basic differences between cajas and banks is that decision making in cajas is influenced by the public authorities. Founded with the backing of regional and local governments, cajas are not-for-profit and so their surplus, after reserves and provisions, is used to finance welfare and cultural activities.

Following the global crisis in 2000, economic growth in Spain was faster than in the rest of Europe, largely due to the close ties between the financial industry and the real estate industry.

In some years, more homes were built in Spain than in England, France and Germany put together. The property boom seemed inevitable, but its adverse consequences were aggravated by the bursting of the real estate bubble in the United States and, above all, the global financial crisis that started in 2007.

The financial industry is burdened by its exposure to the real estate market. Many institutions have foreclosed on mortgaged properties and have taken real estate assets onto their balance sheet. BBVA, for example, has set up a real estate unit that has 30 billion euros in assets.

Spanish banks have also recently come under pressure from the market on account of their capital structure. The results of the stress tests carried out on eurozone banks have been mixed. In July 2011, out of a total of 26 banks and cajas that were subjected to the tests, five (all of them cajas) failed.

Another recent source of concern for banks is the sovereign risk of the eurozone's "peripheral" economies.

For our analysis we have focused on nine banks: Santander, BBVA, CaixaBank, Bankia, Banco Popular Español, Banco Sabadell, Banesto, Bankinter, Banca Cívica and Banco Pastor.

In this paper we analyze board composition and review current banking legislation, the corporate governance model, and board structure and remuneration. We use factor analysis to draw a banking map and cluster analysis to sort banks into homogeneous groups. We find that compliance with good governance recommendations has helped banks and cajas improve their management, but it has not prevented many of them from running into serious difficulties 
because, ultimately, the personal and professional competence of their managers and directors remains decisive, beyond any codes or policies.

\section{Forces of change in the banking industry in Spain ${ }^{1}$}

The "modern" banking industry in Spain came into being following the banking liberalization measures of 1977, which lifted many restrictions on financial institutions, abolished the division of roles between banks, cajas and other financial intermediaries, and gave foreign banks entry into Spain.

These initial measures were followed in later years by the liberalization of fees and interest rates in certain lending and borrowing transactions, the creation of specialized financial intermediaries, the placing of universal banks and cajas on an equal footing, and the adaptation of Spanish laws and regulations to the Second Banking Directive of the EEC, which established the principle of universal banking and created a single banking market in Europe.

In 1987 there were eight large banks in Spain. Although they were among the world's most profitable banks (Banco Popular ranked second), in terms of volume of assets they were insignificant by international standards (Banco Central was the only Spanish bank in the top one hundred, ranking 97th).

Of those eight "large" Spanish banks only three still exist today, two being the result of mergers: Banco Bilbao Vizcaya Argentaria (BBVA), Santander Central Hispano (Santander), which includes Banesto; and Banco Popular, which took over Banco Pastor.

\section{Concept of corporate governance in banks ${ }^{2}$}

Corporate governance is concerned with the mechanisms that ensure efficient utilization of a company's assets, particularly when the assets are used by people other than those who finance them.

The ultimate aim of initiatives to improve corporate governance is to maintain the confidence of society in the financial markets, that is, the capacity to control capital and ensure that any funds received are used to implement profitable projects. Financial institutions are intermediaries, channeling savings toward investment and assuming a share of responsibility for the control of capital.

Generally speaking, there are two views of what constitutes good governance. One, grounded in the agency problems between ownership and control, sees good governance as a set of practices whose ultimate purpose is to maximize a company's stock market value (Shleifer and Vishny, 1997). This is the Anglo-American or external control model of governance. The other is the view that the purpose of good governance is to create value for stakeholders. This is the continental European or internal control model of governance.

External control (or market control) refers to three types of competition: in product and service markets, in capital markets, and in markets for managers. This competition attenuates the problems arising from the separation of ownership and management.

\footnotetext{
${ }^{1}$ Canals (1996).

2 Salas Fumás (2003), Crespí and García (2004), Macey and O’Hara (2003), Tricker (2008). 
Internal control, in contrast, refers to the role played by a company's governing bodies - such as the board of directors - and the composition of these bodies (organizational structure, number of members, presence of independent directors, etc.) in aligning the interests of owners and managers.

Based on geographical criteria, we can identify three different corporate governance systems, as follows:

\section{Table 1}

United States model of corporate governance

\section{United States model}

- The basic model of corporate governance in the United States consists of a single board of directors, with a majority of non-executive directors. The SEC requires that company boards have audit, appointments and remuneration committees.

- Individual shareholders have too little voting power to influence directors through their vote, and so the only options, if they are dissatisfied, are to sell their shares or sue the company.

- The positions of chairman of the board and CEO are usually held by the same person.

- The United States model is rule-based, that is to say: governance is regulated by laws and inflexible mandatory standards.

\section{Table 2}

British model of corporate governance

\section{British model}

- Investors holding no less than $10 \%$ of the voting rights may call extraordinary general meetings and vote on strategic decisions and the removal of directors. The positions of chairman of the board and CEO are usually separated.

- The British model is principles-based, that is to say, the responsibilities of the board are determined by codes of corporate governance, not by law. Companies must either comply with the code of governance or else explain publicly why they do not. Self-regulation is the rule. A company that does not comply exposes itself to the market and may eventually be delisted. The role of regulators is to ensure that investors have sufficient information on which to base their investment decisions.

- Codes of corporate governance call for the appointment of independent directors, audit committees, remuneration committees and appointments committees, and high levels of transparency.

\section{Table 3}

Continental European dual model of corporate governance

\section{Continental European dual model}

Company law is rule-based. The financial markets are smaller and less liquid. The market for corporate control is weaker. Banks are widely used as a source of finance for business and have more influence over company affairs. Investors are generally more concentrated. The dual board model (supervisory board and board of management) is used in Germany and the Netherlands and by some companies in France and Italy. 
Banks have certain unique characteristics that affect the way they are governed. Asymmetric information between managers and outside agents such as dispersed shareholders and creditors (depositors) inhibits effective supervision of management. Controlling shareholders have major incentives to take on risk, as they can transfer it to depositors.

The liquidity production role of banks means that they typically receive more than $90 \%$ of their funding from debt, holding illiquid assets and issuing liquid liabilities. Banks must carefully manage the trust of their depositors to avoid bank runs. Deposit insurance has been created to reinforce depositors' trust in banks. In addition, capital requirements have been established to prevent excessive borrowing with limited liability for shareholders.

Regulation reduces competition and hence risk taking, which enhances the value of banks' own funds and thus also their solvency. Reduced competition, however, increases moral hazard. Supervision and control are tasks for the regulator, rather than shareholders or depositors. As a result, market discipline and internal control mechanisms play a smaller role.

\section{Banking law and regulation}

\section{Good governance codes in Spain ${ }^{3}$}

Spain's first answer to the pioneering Cadbury Report on good corporate governance, published in the United Kingdom in 1992, was the 1998 Olivencia Report. This was the first of three corporate governance codes.

The Olivencia Report recommended that boards have a majority of non-executive directors (i.e., who are not members of the company's management team); that safeguards be put in place where the positions of chairman and CEO are not separated; that board committees be established; that board meetings be held with the appropriate frequency; and that the number of directors be limited to ensure effective decision-making. Its aim was to "modernize boards and make them more operational and transparent, so that they serve companies' interests more effectively".

Next came the Aldama Report in 2003. Here the emphasis was on transparency of governance in general (not only the board of directors), the duties of loyalty and care, disclosure of conflicts of interest, the functioning of boards of directors and general meetings, and the relationship between listed companies and other companies with which they have business relationships or from which they receive advisory services.

It is worth noting that the Aldama Report was published one year after the Sarbanes-Oxley Act (SOX), which is mandatory for United States listed banks, was passed in the United States. SOX establishes more comprehensive control in order to restore trust in accounting practices (creating a Public Company Accounting Oversight Board), with more efficient controls, specifically over CEOs.

\footnotetext{
${ }^{3}$ Olivencia Report, Aldama Report, Unified Code. 
Lastly, in 2006, came the Unified Code for companies that are listed on the Spanish stock exchanges. This code is unified in the sense that it combines the previous two. It also takes account of the EU Recommendations issued in December 2004 and February 2005. The former concern the remuneration of the directors of public companies, while the latter address the role of non-executive directors and the creation of supervisory committees.

The degree to which these good governance practices are put into effect varies widely. According to a classification devised by McKinsey \& Co., there are five stages of governance. In the first three (compliance, ethical standards, and risk mitigation), the goal is "not to destroy value", whereas in the fourth and fifth stages (building trust in the markets and improving competitiveness), the aim is to "create value".

\section{Banking laws and regulations in Spain ${ }^{4}$}

The Spanish banking system is overseen by the Banco de España. The Banco de España is empowered by law to issue so-called "monetary circulars", through which it exercises the monetary policy functions assigned to it within the European System of Central Banks. Its other powers are exercised through another type of circular, in accordance with the laws and regulations under which it operates. Both types of circular are published in the Official State Gazette (Boletin Oficial del Estado).

In Spain banks require authorization by the Ministry of Economy and Finance, subject to a report by the Banco de España.

They must also meet a series of requirements. Most notably, they must be duly incorporated; have a minimum capital stock of 18 million euros, fully paid in cash and represented by registered shares; limit their object to the activities proper to credit institutions; ensure the commercial and professional good standing of significant shareholders (i.e., shareholders who hold 5\% or more of the capital or voting rights); have a board of directors made up of at least five members, all of good repute and with appropriate knowledge and experience; have a sound administrative and accounting organization and appropriate internal audit procedures, so as to guarantee healthy and prudent management; and have their registered office and principal place of business in Spain.

To assess a person's "commercial and professional good standing”, the banking regulator reviews the person's record of respect for the law and maintenance of good commercial, financial and banking standards.

The regulator has also established criteria for assessing the suitability of significant shareholders, namely, commercial and professional good standing; resources; transparency of the structure of the group to which the institution belongs, if any; removal of impediments to effective inspections; and measures to prevent shareholders' non-financial activities from giving rise to excessive risks for the bank.

New banks are subject to limitations and prohibitions during the first few years. A newly created bank is not allowed to pay dividends for the first three years, for example, and for the first five years it is not allowed to extend loans or guarantees to members, directors or senior managers, close relatives of directors, or companies in which directors or close relatives of directors hold

\footnotetext{
${ }^{4}$ Banco de España and Salas Fumás (2003).
} 
more than 15\% of the capital or are directors. Also, for the first five years any transfer of shares in the bank must be authorized by the Banco de España, and no company or group may hold more than 20\% of the bank's capital or exercise control over the bank. The purpose of all this is to protect savers against possible opportunistic behavior by the bank's sponsors.

In carrying on its business, a credit institution must also comply with capital adequacy rules, which in Spain are stricter than the harmonized EU rules. Eligible capital is defined more narrowly, for instance, and the limit on investments in non-financial businesses is lower (10\% compared to $15 \%$ in the EU).

As regards accounting, valuation rules and reporting, the Spanish standards are more detailed than the EU rules and demand minute treatment of credit risk and credit risk coverage (through specific, generic and statistical provisions).

Under Law 26/1988, the Banco de España subjects individuals or corporations who wish to acquire or increase an equity interest in a financial institution to special scrutiny. Disclosures are required and the regulator may oppose the proposed acquisition in the interests of the longterm healthy and prudent management of the institution.

The main provisions on significant shareholdings are contained in Law 26/1988 (Title VI), under which any person, natural or legal, who intends to directly or indirectly acquire an interest in the capital of a bank is required to disclose his intention to the Banco de España in advance of the acquisition if the intended acquisition will bring the person's total interest above any of the following thresholds: 10\%, 15\%, 20\%, 25\%, 33\%, 40\%, 50\%, 66\% and 75\%. The Banco de España may oppose the acquisition if it considers that the equity holder does not meet the requirements of good repute and professionalism. Failure to comply with the above disclosure requirement is punishable with forfeiture of the voting rights associated with the acquired shares and possibly an administrative sanction.

Authorization from the Ministry of Economy and Finance is also required for mergers, takeovers and demergers among banks. The Banco de España reports to the Ministry on any prudential concerns raised by such transactions.

The Law on Discipline and Intervention of Credit Institutions establishes a system of penalties for credit institutions that break the rules and for people who hold posts of responsibility in such institutions. The penalties can range from a simple private warning to a fine equal to $1 \%$ of the bank's equity or the revocation of its license to operate.

It is the Banco de España that takes disciplinary action and imposes penalties, as appropriate, for both minor and serious infractions. In the case of very serious infractions, however, penalties may be imposed by the Ministry of Finance, at the proposal of the Banco de España, except where the penalty involves the withdrawal of the infringing institution's license to operate in the market, which can only be decided by the Spanish Cabinet.

In addition, where a credit institution is in an exceptionally serious situation, such that its capital adequacy or its stability, liquidity or solvency is in jeopardy, Law 26/1988 provides for public intervention in credit institutions and the replacement of their governing bodies or management. The above is applicable where there is concrete evidence of the seriousness of the situation, although the true situation of a credit institution cannot be deduced from its accounts. 
The Ministry of Economy and Finance is empowered to establish and modify the accounting rules and the standard forms for financial reporting. In practice, this power is delegated to the Banco de España. Even so, in establishing and modifying said rules and standard forms, a prior report from the Institute of Accounting and Auditing (ICAC) is required. Also, the Ministry of Economy and Finance may issue rules on the content and dissemination of banking contracts between credit institutions and their customers.

Regulation has become a control mechanism that may leave little scope for the voluntary adoption of good governance practices. It may also limit the ability of external control mechanisms to promote efficiency in the banking industry. Regulation will influence the functioning of the internal and external control mechanisms, as we shall see.

\section{Corporate governance model in Spanish banks}

Corporate governance in Spanish banks is governed by each bank's bylaws, as well as by the regulations of the board of directors and the general meeting. In what follows we take a close look at the governing bodies of the four largest Spanish banks, namely, Santander, BBVA, CaixaBank and Bankia. As we will see, all four have similar governance systems, in line with the provisions of Spanish law and the Unified Code on Good Corporate Governance.

All four banks have two governing bodies: a board of directors and a general meeting.

\section{Board of Directors}

\section{Functions}

The board of directors is the highest decision-making body, except in matters reserved to the general meeting.

The board delegates daily management of the company to the executive body and concentrates on its oversight role, which entails the following responsibilities, among others: approval of company policy and strategy, approval of shareholder information and communication policy, approval of directors' remuneration, appointment and removal of senior managers, monitoring of management activities, and assessment of managers' performance.

\section{Composition}

The number of directors, the appointment and removal of directors, and the ratification of coopted directors is decided by the general meeting (the board is authorized to fill vacancies, as they arise, by co-option). Any nominations submitted to the general meeting by the board of directors must be preceded by a report from the appointments committee.

As a general rule, there should be more non-executive (external) than executive directors and at least one third of the non-executives should be independent.

Article 5.3 of the board regulations of CaixaBank requires that the ratio of proprietary to independent directors reflect the ratio of the shares represented by proprietary directors to the remaining shares, and also that at least one third of the directors be independents. 
Rather than specifying a minimum proportion of independents, article 38 of the board regulations of Bankia encourages the general meeting to elect a "reasonable" number.

The number of directors the four banks consider acceptable varies. At Santander the board must have between 14 and 22 members, while at CaixaBank the range is 12 to 20. At BBVA the minimum is 5 and the maximum 15, while Bankia specifies a range of 5 to 19 .

\section{Executive Committee}

In all the banks in our sample the executive committee is chaired by the chairman of the board of directors. The executive committee has all the functions that can be delegated to it by the board.

The executive committee of BBVA has a majority of non-executive directors, and at least onethird are independents. Its functions are to assess the corporate governance system, formulate and propose general policy, decide the overall level of investment in each business activity, and order audits, among other things.

In Bankia the executive committee handles matters within the jurisdiction of the board where an urgent decision is required (subject to subsequent ratification). It has powers in three areas: management, organization, and risk. The committee's management powers include proposing short and long-term policies, objectives and programs; assessing the work of board committees; and making proposals to the board regarding corporate governance. In the area of organization and control, the executive committee submits to the board proposals regarding the principles that should inform the corporate structure. Issues relating to risk are dealt with by the executive committee, rather than by a specific risk committee.

\section{Chairman}

The chairman of Banco Santander is also the chief executive. The board may however, appoint additional CEOs, giving them such functions as it deems appropriate. Currently, the banking group's CEO is Alfredo Saenz.

At BBVA, the chairman is appointed by the board, and the roles of chairman and chief executive are not separated. Francisco Gonzalez is chairman and CEO. In September 2009 the board appointed an additional CEO, Ángel Cano, with powers delegated by the chairman.

The bylaws of CaixaBank do not give the chairman of the board the rank of CEO.

In Bankia the board elects the chairman, who remains the chairman for as long as he remains a director. The chairman is at the same time the bank's chief executive.

\section{Board Committees}

At Banco Santander there are six board committees: the executive committee, which has delegated decision-making power; the risk committee; the audit and compliance committee; the appointments and remuneration committee; the international committee; and the technology, productivity and quality committee.

The risk committee is responsible for making proposals to the board with regard to risk policy, the review of risk exposure, knowledge and authorization of risk management tools, compliance with supervisory requirements, adherence to agreed risk thresholds, and authorization of transactions 
referred to it by junior bodies. It is made up of four to six directors. Currently, it consists of 40\% executive directors and 60\% external non-proprietary directors.

The audit and compliance committee is responsible for reporting to the general meeting on issues raised by shareholders that fall within its ambit; monitoring the effectiveness of the bank's internal controls; overseeing the preparation and presentation of statutory financial information; advising on the appointment of the statutory auditor; and issuing an annual report on the independence of the statutory auditor. It has three to seven members, all of them non-executive and a majority independent. Currently, all the members are independents.

The appointments and remuneration committee has the following responsibilities, among others: to develop rules on board composition and director selection, annually to review directors' qualifications, and to submit proposals on remuneration policy and directors' and senior managers' remuneration. It has three to seven members, all of them non-executive and a majority independent. Currently, all the members are independents.

In addition to these committees, which are found in most banks, Banco Santander has two more. The first is the international committee, which is responsible for monitoring the progress of the group's strategy and activities in the markets and countries in which the group wishes to be present. The second is the technology, productivity and quality committee, which assesses the bank's IT plans. Both committees are chaired by the bank's chairman, Emilio Botín.

BBVA has five board committees: a risks committee, an audit and compliance committee, an appointments committee, a remuneration committee, and the executive committee.

The audit and compliance committee is made up entirely of independent directors, none of whom may be members of the executive committee. It has no fewer than four members, all of whom are appointed by the board. Its role is similar to that of the audit and compliance committee at Banco Santander.

The appointments committee advises the board in matters relating to the appointment of directors. It has no fewer than three members, all appointed by the board. All are external and most are independent, including its chairman. The committee's functions are as follows, among others: to submit proposals for the appointment and reappointment of directors, annually review directors' status, and report on the work of the chairman.

Unusually, BBVA has a separate remuneration committee, which assists the Board in matters concerning directors' and senior managers' remuneration. It has no fewer than three members, appointed by the board, all non-executive and most of them independent, including the chairman. The functions of the remuneration committee are to propose the system of directors' remuneration, issue an annual report on directors' remuneration, and make proposals to the board regarding the remuneration of senior executives.

The risk committee is made up of a majority of external directors, appointed by the board of directors. Its functions are, among others, to analyze and assess proposals on strategy and monitor risk management policies; to monitor the appropriateness of the risks assumed and the resulting risk profile; and to evaluate and, as the case may be, approve risks that have the potential to jeopardize the group's solvency.

In the case of CaixaBank, the board of directors appoints an appointments and remuneration committee made up of between three and five directors. 
It also creates an audit and control committee, with between three and seven members, a majority of whom are non-executives. At least one of the members of the audit committee is independent and is chosen based on his knowledge and experience in the field of accounting, auditing or both. In all cases the members of the committees are appointed by the board of directors. The chair of the audit and control committee is chosen from among the non-executive directors and is replaced every four years. The committee's powers are same as in the other banks.

In Bankia, the board of directors is permitted to create and maintain an executive committee and is required to create an audit and compliance committee, an appointments and remuneration committee, and a risk committee. The audit and compliance committee is chaired by an independent director, who must have knowledge and experience of accountancy, auditing or risk management. The chair of the audit and compliance committee is replaced every four years. The committee's powers are those described earlier.

The appointments and remuneration committee is made up of between three and seven directors, all of whom must be non-executives. The members of the appointments and remuneration committee are appointed by the board of directors. The appointments and remuneration committee is chaired by a non-executive director appointed by the board and has general authority to submit proposals and report on remuneration and on the appointment and removal of directors and senior managers.

The risk committee is responsible for establishing and monitoring compliance with the bank's risk control mechanisms and for authorizing the most important transactions and setting overall limits, within which lower authorities may authorize the rest, all this without prejudice to the supervisory powers of the audit and compliance committee. It has three to seven members and is chaired by a director appointed by the board. The risk committee is an executive committee and so may adopt resolutions under powers delegated to it by the board.

\section{General Meeting}

The general meeting is the supreme decision-making body of the company and its resolutions are binding on all shareholders. General meetings may be ordinary or extraordinary. Ordinary general meetings are held annually in the first half of the financial year to review the company's management, receive the previous year's accounts, decide on the allocation of profit, and where necessary approve the consolidated accounts, without prejudice to the meeting's authority to debate and resolve on any other business stated in the agenda.

Apart from the annual general meeting, general meetings may be called by the board of directors when so requested by shareholders representing no less than five ${ }^{5}$ percent of the shares, stating in their request the business to be transacted, always provided the board considers the proposed meeting to be in the company's interest. The board of directors draws up the agenda, which will include the business stated in the request.

The general meeting has, among others, the power to amend the company's bylaws; confirm or rectify the board's interpretation of the bylaws; determine the number of directors; appoint, reappoint and remove directors; ratify or revoke directors co-opted by the board; and increase or reduce capital.

\footnotetext{
${ }^{5}$ Except Bankia, which does not set a minimum percentage. 


\section{Table 4}

Board and executive committee composition

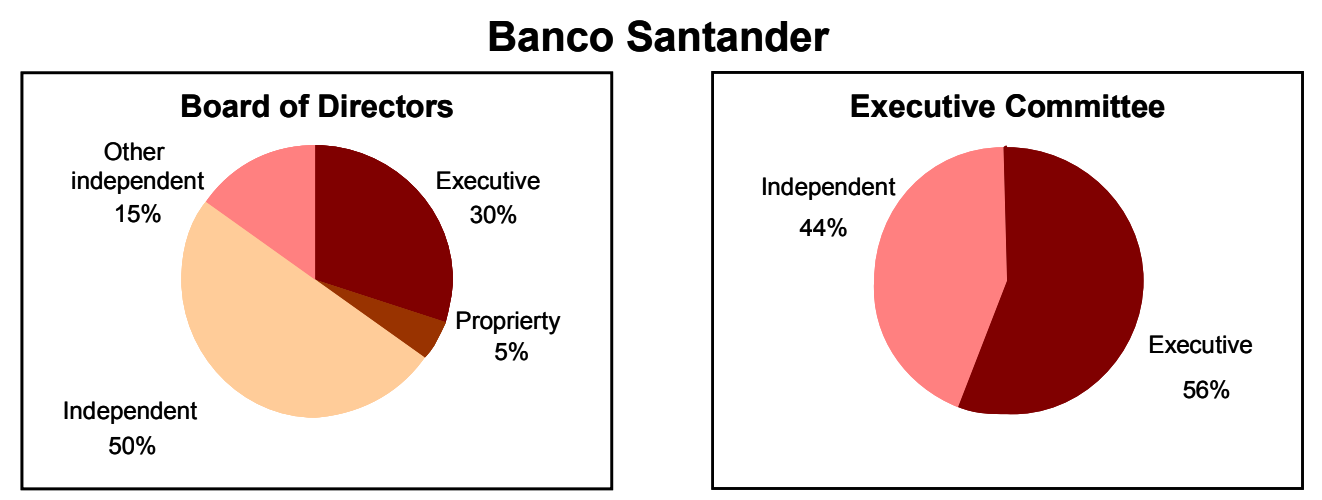

\section{BBVA}
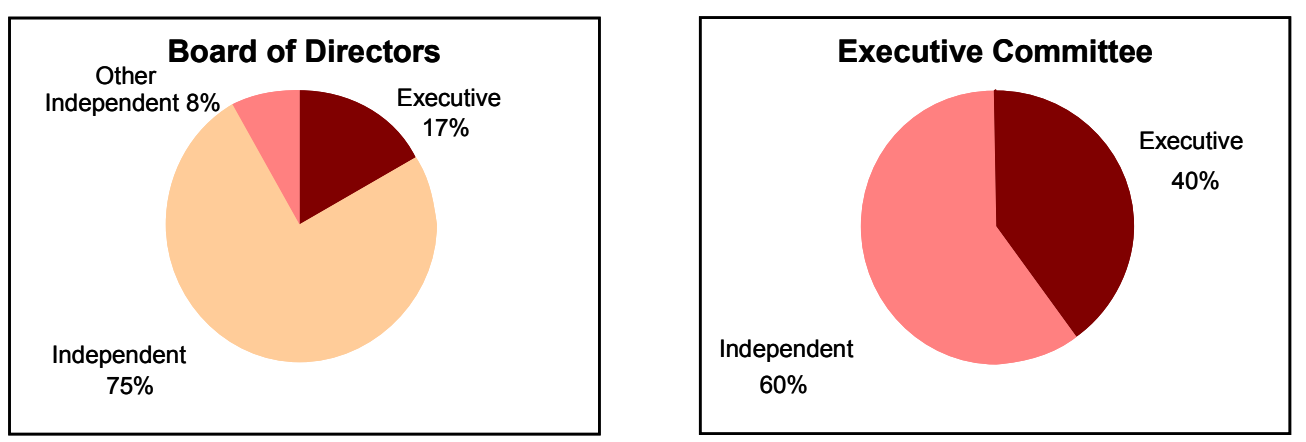

\section{CaixaBank}
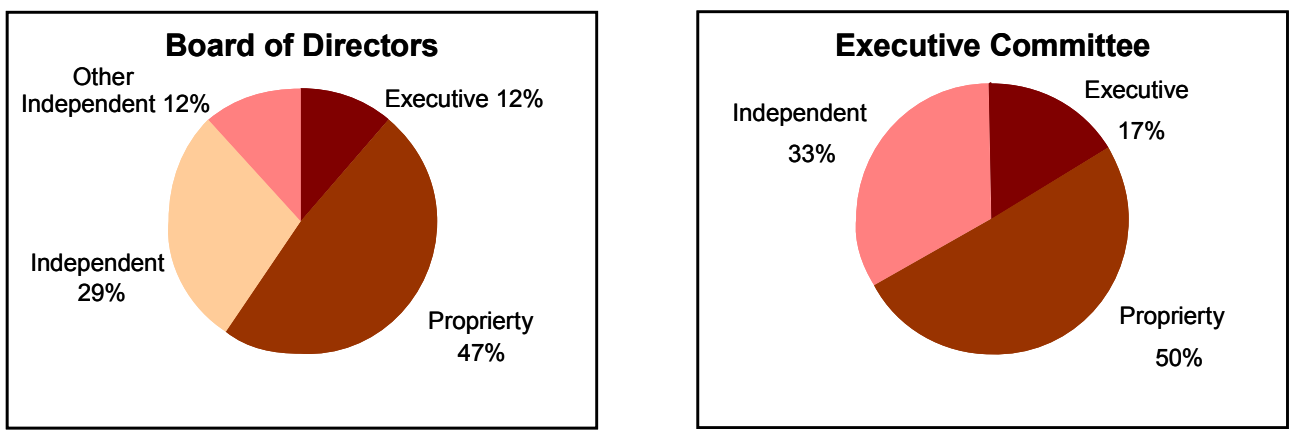

\section{Bankia}
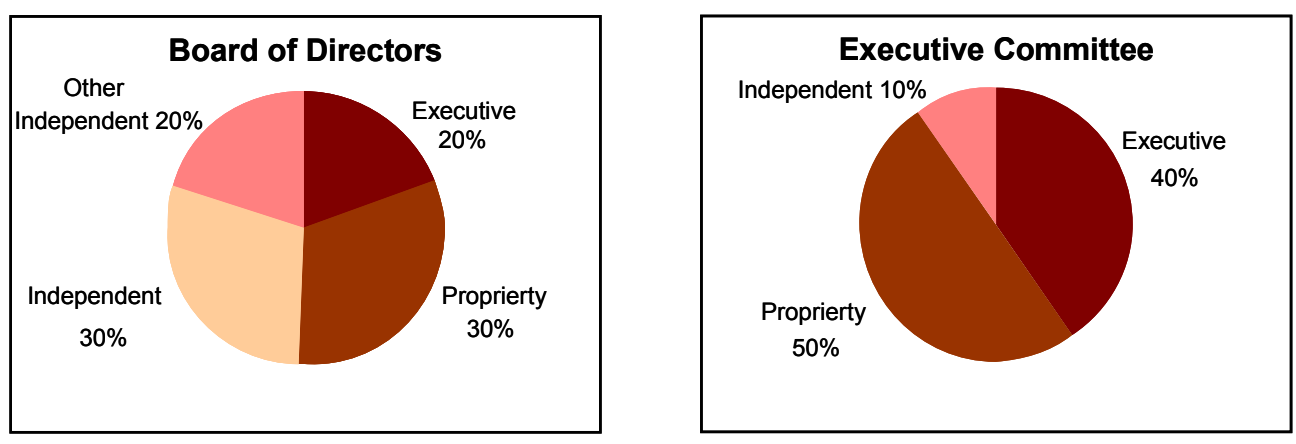


\section{Ownership structure}

Our analysis of ownership structure is based on the scheme provided by Salas Fumás (2003). We shall use two variables:

- Type of control of the company. Absolute control is when the largest shareholder controls at least $80 \%$ of the voting power; majority control is where the majority shareholder holds between 50\% and 80\% of the shares; minority control is when the main shareholder owns less than $50 \%$ of the capital and the remaining shareholders have sufficiently diluted power to exercise control; and internal control is when there are no significant shareholders.

- Degree of concentration of ownership. Depending on the number of significant shareholders, we classify ownership concentration as high, medium or low.

\section{Type of control}

The Spanish banks are classified as follows:

\section{Table 5}

Type of shareholder control

\begin{tabular}{lccl}
\hline \multicolumn{4}{c}{ Control } \\
$\begin{array}{c}\text { Absolute } \\
\mathbf{8} \mathbf{8 0} \%\end{array}$ & $\begin{array}{c}\text { Majority } \\
\mathbf{5 0 \% - 8 0 \%}\end{array}$ & $\begin{array}{c}\text { Minority } \\
\mathbf{5 \%}-\mathbf{5 0 \%}\end{array}$ & $\begin{array}{c}\text { Internal } \\
<\mathbf{5} \%\end{array}$ \\
\hline CaixaBank & Bankia & Bankinter & Santander \\
Banesto & B. Cívica & B. Popular & BBVA \\
& & B. Pastor & \\
& & B. Sabadell \\
\hline
\end{tabular}

CaixaBank and Banesto are under the absolute control of a single shareholder. In both cases the main shareholder has more than $80 \%$ of the voting power.

CaixaBank is controlled by Caja de Ahorros y Pensiones de Barcelona, which has an interest of more than $80 \%$ and is represented on the board of directors by eight proprietary directors (47\% of the total).

Banesto is controlled by Banco Santander, which owns 90\% of the shares and is represented on Banesto's board by three proprietary directors (21\% of the total), one of whom is the chairman, Antonio Basagoiti. 
At the opposite extreme are the two largest Spanish banks. Neither Santander nor BBVA has significant shareholders. In this respect, their ownership structure is closer to the United States or British model.

Midway between the extremes are Bankia and Banca Cívica, both of them the result of "cold mergers" ${ }^{6}$ between cajas (Caja Madrid, Bancaja, La Caja de Canarias, Caja Ávila, Caixa Laietana, Caja Segovia and Caja Rioja, in the case of Bankia; and Caja de Navarra, CajaCanarias, Caja de Burgos and Cajasol, in the case of Banca Cívica).

\section{Degree of concentration}

The shareholders of Spanish banks include a significant proportion of custodian banks. In the case of Santander, Chase Nominees has an interest of 10.24\%, State Street Bank 9.52\%, EC Nominees 6.45\%, The Bank of New York Mellon 5.05\%, Guaranty Nominees Limited 3.73\% and Société Générale 3.28\% ${ }^{7}$.

These shareholdings are not recognized by the CNMV as significant, as the custodian banks are not the owners of the shares but merely depositaries that have taken over certain management responsibilities with respect to the shares.

In the case of BBVA, Chase Nominees has an interest of 6.89\% and State Street Bank 5.25\%.

Blackrock holds 1.16\% of Banco Popular, 4.92\% of BBVA, 3.12\% of Banco de Sabadell, 0.22\% of CaixaBank, $0.67 \%$ of Bankinter and 4.78\% of Banco Santander.

The dispersion of ownership characteristic of the United States and British corporate governance model is very clearly manifested in the two largest Spanish banks, Santander and BBVA. Both have no significant shareholders, i.e., not just shareholders who hold more than a certain proportion of the shares, which is a mere convention, but shareholders who, besides holding $3 \%$ or more of the shares, actively exercise their rights in general meetings.

\footnotetext{
6 "Cold mergers" are mergers between credit institutions in the form of an "Institutional Protection Scheme" (Sistema Institucional de Protección). This type of scheme was first introduced in 2008 as a means of restructuring the Spanish cajas. ${ }^{7}$ Data from the annual report.
} 


\section{Table 6}

Largest shareholder in Spanish banks

\section{Largest shareholder ${ }^{8}$}

\begin{tabular}{l|cl|}
\hline Santander & 4.8 & Blackrock Inc. \\
B. Sabadell & 5.0 & Mayor Vent, SLU \\
BBVA & 5.1 & Manuel Jove Capellán \\
B. Popular & 14.4 & Sociedad General Financiera, S.A. \\
Bankinter & 23.9 & Jaime Botín-Sanz de Sautuola y García de los Ríos \\
B. Pastor & 42.2 & Fundación Pedro Barrié de la Maza \\
Bankia & 52.4 & Banco Financiero y de Ahorros, S.A. \\
B. Cívica & 55.3 & Caja Navarra, Caja Sol, CajaCanarias, Caja de Burgos \\
CaixaBank & 81.5 & Caja de Ahorros y Pensiones de Barcelona \\
Banesto & 90.0 & Banco Santander, S.A. \\
Mean & 37.5 & \\
Median & 33.0 & \\
Mean lbex35 & 34 &
\end{tabular}

Source: CNMV and Observatorio de Gobierno Corporativo 2010, FEF.

High shareholder concentration (37.5\% of the voting rights of the average Spanish bank are held by a single shareholder) is characteristic of the Spanish model of corporate governance, in line with other countries in continental Europe.

To assess the uniformity of the distribution of the largest shareholdings, the two charts below show the percentage of capital held by the largest shareholder and the three largest shareholders in each bank.

In the first chart we see that in 50\% of the banks the majority shareholder holds $25 \%$ of the shares or less. In the second chart, we see that in 50\% of the banks the three largest shareholders together hold $45 \%$ of the shares or less. The second distribution is more uniform than the first.

${ }^{8}$ CNMV. 


\section{Figure 1}

Distribution of shareholder concentration
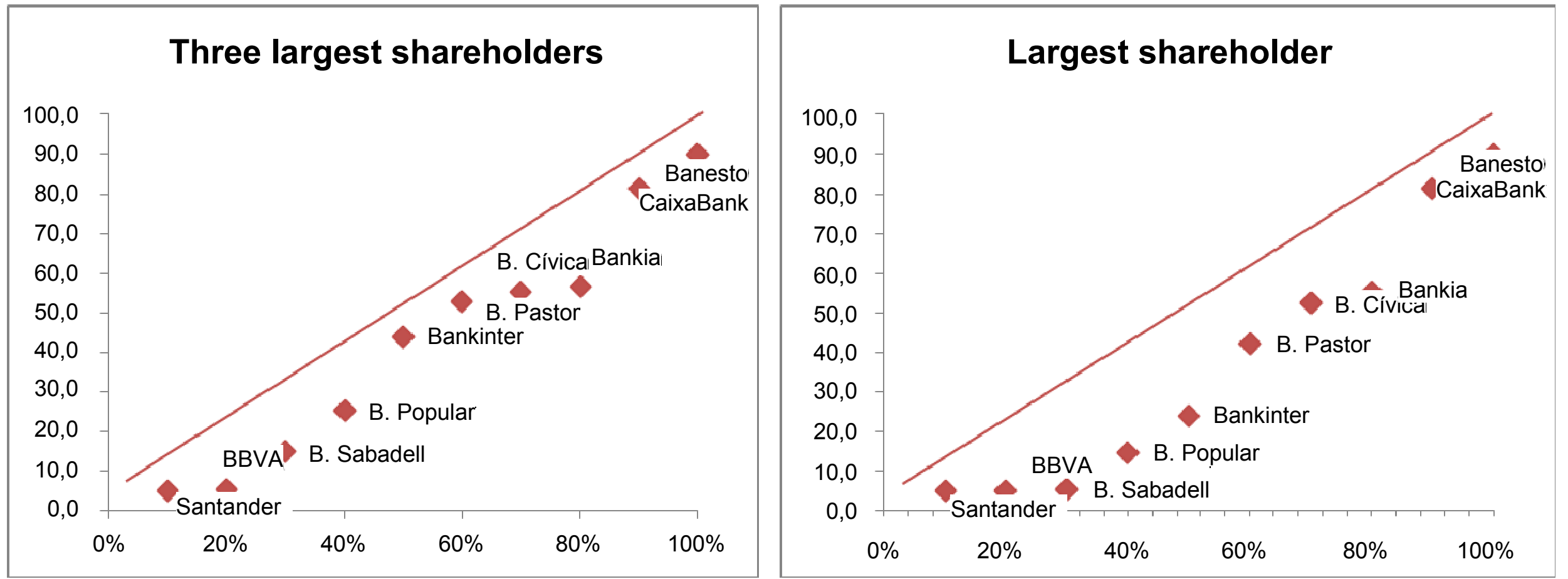

Source: compiled by the author. 


\section{Table 7}

Degree of concentration

\section{Degree of concentration}

\begin{tabular}{|c|c|c|c|c|c|c|c|c|c|}
\hline \multirow{3}{*}{$\begin{array}{l}\text { No. of } \\
\text { significant } \\
\text { shareholders }\end{array}$} & High & & & Average & & & Low & & \\
\hline & 1 & 3 & 4 & 5 & 6 & 7 & 8 & 9 & 10 \\
\hline & $\begin{array}{l}\text { CaixaBank } \\
\text { Banesto } \\
\text { Bankia } \\
\text { B. Cívica }\end{array}$ & Bankinter & B. Popular & & $\begin{array}{l}\text { B. Sabadell } \\
\text { B. Pastor }\end{array}$ & & & & \\
\hline
\end{tabular}

Source: compiled by the author.

\section{Table 8}

Shares held by directors and institutional investors

\begin{tabular}{l|ccclcc|} 
& Board & Institutional & Free float & Chairman & Shareholding & \% of the board \\
\hline Santander & 2.9 & 54.6 & 96.7 & Emilio Botín & 1.922 & 66 \\
BBVA & 0.07 & 46 & 93.6 & Francisco González & 0.052 & 74 \\
CaixaBank & 0.081 & $6.4^{9}$ & 20.1 & Isidro Fainé & 0.017 & 21 \\
Bankia & 0.038 & $23.8^{10}$ & 43.0 & Rodrigo Rato & 0.004 & 11 \\
B. Popular & 42.1 & 26.5 & 57.4 & Ángel Ron & 0.005 & 0 \\
B. Sabadell & 7.2 & 37.9 & 76.4 & José Oliu & 0.322 & 4 \\
Banesto & 0.02 & $4.9^{11}$ & 9.9 & Antonio Basagoiti & 0 & 0 \\
Bankinter & 25.6 & $26.1^{12}$ & 44.1 & Pedro Guerrero & 0.651 & 3 \\
B. Cívica & 0.042 & $17.9^{13}$ & 47.5 & Antonio Pulido & 0.005 & 12 \\
B. Pastor & 0.245 & 18.0 & 41.5 & José María Arias & 0.147 & 60 \\
\hline
\end{tabular}

Source: compiled by the author based on data from the CNMV and IAGC.

\footnotetext{
${ }^{9}$ Institutional shareholders as a proportion of total share capital, not including the majority shareholder, la Caja de Ahorros y Pensiones de Barcelona.

${ }^{10}$ Excluding the interest held by Banco Financiero y de Ahorros.

${ }^{11}$ Not including the interest held by Banco Santander.

${ }^{12}$ Not including the interests of the two significant shareholders, Cartival and Crédit Agricole.

${ }^{13}$ Institutional shareholders as a proportion of total share capital, not including the cajas that are the majority shareholders.
} 


\section{Board composition and structure}

\section{Table 9}

Recommendations of the Unified Code

\section{Recommendations of the Unified Code regarding board structure}

- The board should have more than 5 and fewer than 15 members. (Recommendation 9)

- There should be a majority of non-executive directors. The number of executive directors should be the minimum required considering the complexity of the company and the executives' interest in the company. (Recommendation 11)

- The ratio of proprietary to independent directors should reflect the ratio of the equity represented by proprietary directors to total equity. (Recommendation 12)

- The proportion of proprietary directors may be greater in companies with high market capitalization, where the absolute value of the shareholdings is high, even though they do not legally qualify as significant, or in companies in which the board includes representatives of a large number of shareholders who are unrelated to one another. (Recommendation 12)

- At least one third of the total number of directors should be independents. (Recommendation 13)

- When a company's chairman is also its chief executive, a lead independent director should be empowered to request the calling of board meetings or the inclusion of new business on the agenda; to coordinate and give voice to the concerns of non-executive directors; and to lead the board's assessment of its chairman.

- Independent directors should not stay on as such for a continuous period of more than 12 years. (Recommendation 29)

Source: compiled by the author based on the Unified Code.

\section{Board size}

The average number of directors per bank is 14.9, with a standard deviation of 3.9. The banks with the largest boards are Santander and Bankia, both with 20 directors, and Banco Popular and CaixaBank, with 18 and 17 directors, respectively. At the opposite extreme are Banco Pastor and Bankinter, with 9 and 10 directors. 


\section{Table 10}

Number of directors

\begin{tabular}{lr} 
& \# directors \\
\hline Santander & 20 \\
BBVA & 12 \\
CaixaBank & 17 \\
Bankia & 20 \\
B. Popular & 18 \\
B. Sabadell & 15 \\
Banesto & 14 \\
Bankinter & 10 \\
B. Cívica & 14 \\
B. Pastor & 9 \\
Average & 14.9 \\
Median & 14.5 \\
Ibex35 average & 14.4 \\
Mercado Continuo average & 11.2
\end{tabular}

Source: IAGC and Observatorio de Gobierno Corporativo 2010, FEF.

Lastly, the average size of the boards of directors of Spanish banks is very close to the average for companies in the Ibex 35 index, namely 14.4, close to the upper limit recommended by the Unified Code.

\section{Directors}

Spanish law recognizes three types of directors. Depending on their contractual relationship with the company, there are executive directors and independent non-executive directors. Unique to Spain are the third type, proprietary directors, i.e., directors who represent a significant shareholder.

The most common type of director on the boards of Spanish banks is independent directors, averaging $44 \%$ of the total. The proportion of independents ranges from $75 \%$ in BBVA to $29 \%$ in CaixaBank and Banca Cívica.

Proprietary directors account for $26 \%$ on the average, 10 percentage points below the average for Ibex 35 companies. The proportion of proprietary directors is particularly high in the banks that are the result of mergers between cajas, which is to say, CaixaBank ${ }^{14}$, Bankia ${ }^{15}$ and Banca Cívica ${ }^{16}$. In all three cases the proportion of proprietary directors is above average, as high as 57\% in Banca Cívica. In these banks, all the proprietary directors represent cajas.

\footnotetext{
${ }^{14}$ Controlled by Caja de Ahorros y Pensiones de Barcelona.

${ }^{15}$ Created in June 2010 through the merger of Caja Madrid, Bancaja, La Caja de Canarias, Caja de Ávila, Caixa Laietana, Caja Segovia, and Caja Rioja.

${ }^{16}$ Created through the merger of Caja Navarra, Caja Canarias, Caja de Burgos and Cajasol. 
Executive directors, on the other hand, account for $20 \%$ of the boards in our sample, close to the average of $17.2 \%$ for Ibex 35 companies. Santander and Bankinter are the two with the highest proportion of executive directors (30\%).

\section{Figure 2}

Distribution of directors by bank

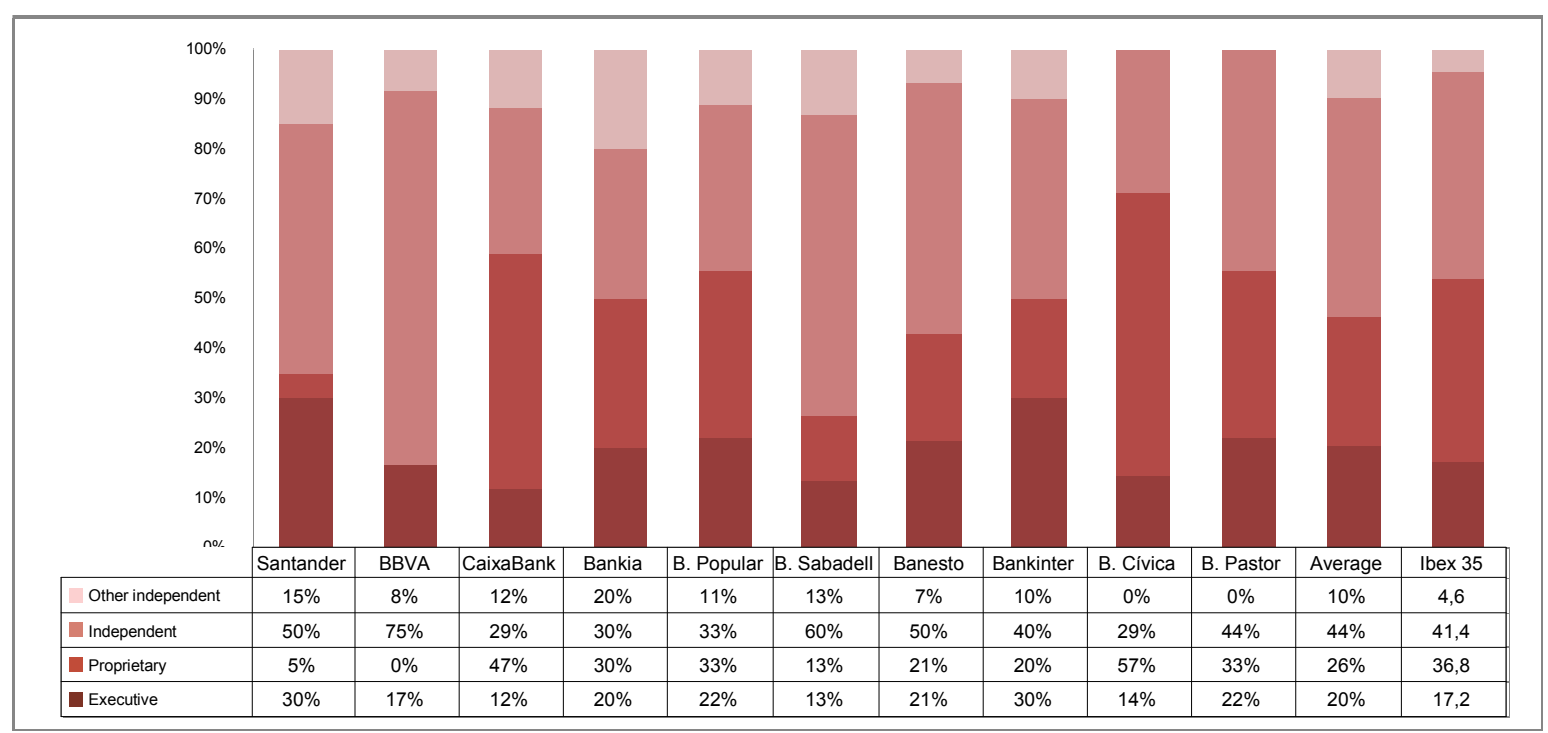

Source: compiled by the author based on data from IAGC and Observatorio de Gobierno Corporativo 2010, FEF.

\section{Figure 3}

Distribution of directors by bank

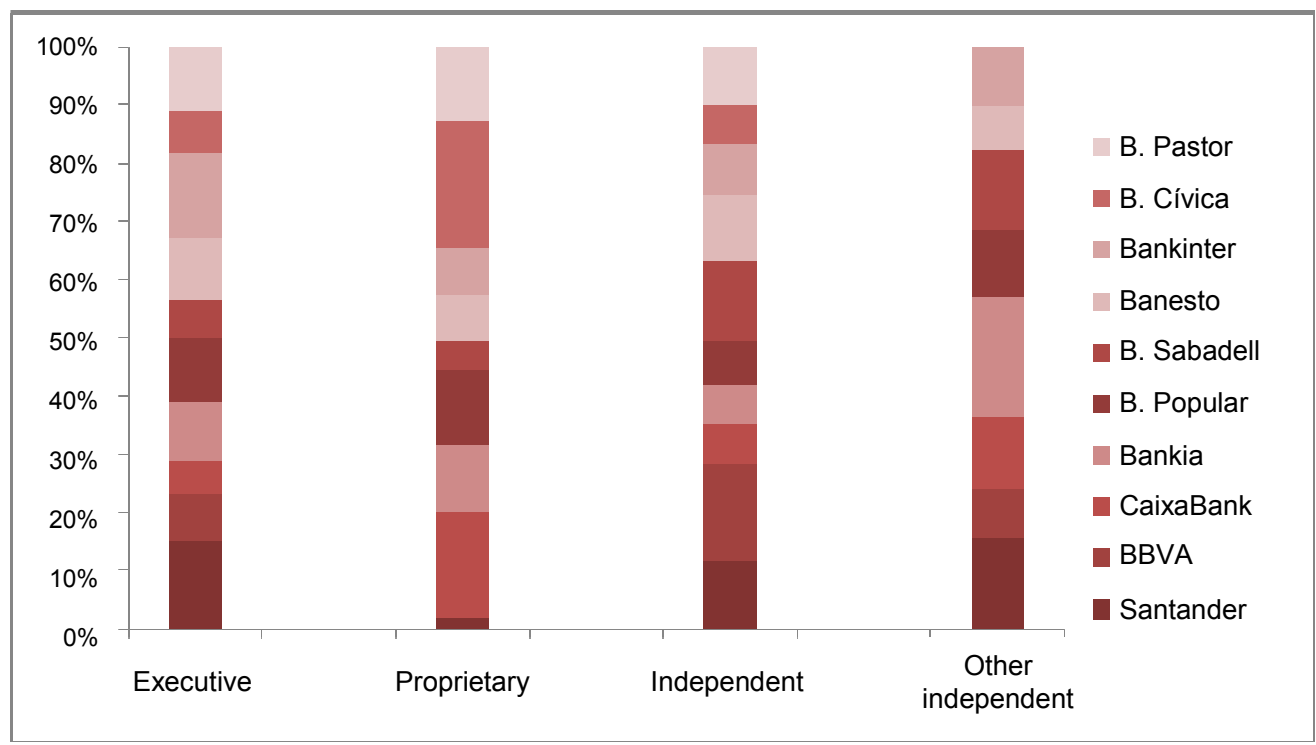

Source: compiled by the author based on data from IAGC.

Another issue addressed by corporate governance scholars is the representation of the various shareholder groups on the board. There are two ratios we can use to assess whether, within the float, significant shareholders and minority shareholders are over-represented or under-represented. 
Proprietary directors represent significant shareholders, so the percentage of proprietary directors on the board should be similar to the percentage ownership interest they represent.

On the other hand, independent directors serve to represent small shareholders, so the percentage of independent directors on the board should tell us how well the free float is represented.

The following chart shows the value of each ratio for the banks in our sample.

\section{Figure 4}

Representation of large shareholders and minority shareholders on the board

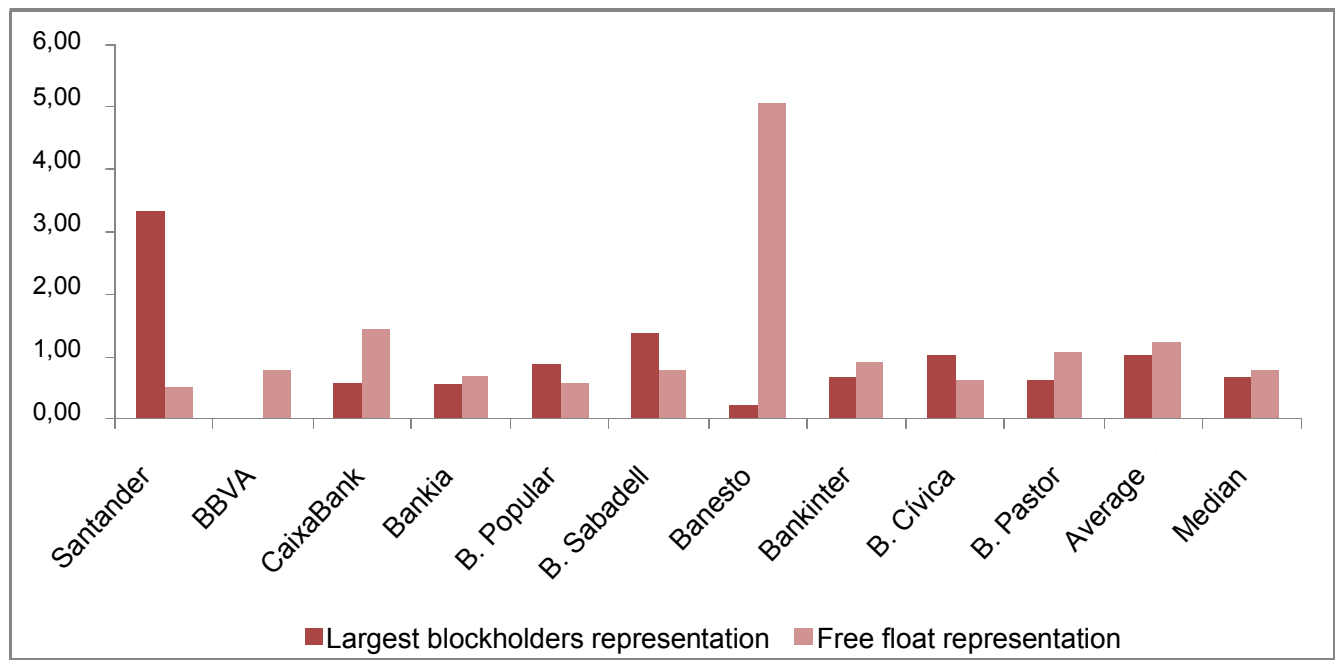

Source: compiled by the author.

According to Observatorio de Gobierno Corporativo 2010, published by Fundación de Estudios Financieros, the representativeness index of significant shareholders for companies traded in the continuous market was 0.97, slightly below the value we calculate for the banking sector in 2010 . On the other hand, according to the same publication, the representation of the float in 2009 was 1.87.

Recommendation 12 of the Unified Code on Good Corporate Governance proposes that the proportion of proprietary directors to independent directors should reflect the proportion of the shares represented by proprietary directors to the remainder of the shares.

The following table shows Spanish banks according to the relative bias toward proprietary or independent directors on the board:

$\begin{array}{ll}\text { Independent director bias } & \text { Proprietary director bias } \\ \text { CaixaBank } & \text { B. Cívica } \\ \text { B. Pastor } & \text { B. Sabadell } \\ \text { Banesto } & \text { B. Popular } \\ \text { Bankia } & \text { Santander } \\ \text { Bankinter } & \end{array}$

The strongest bias is found in Banesto, CaixaBank and Banca Cívica. Banesto and CaixaBank are subsidiaries of Banco Santander and Caja de Ahorros y Pensiones de Barcelona, respectively. 
Although in both cases the parent's interest is around 80\%, there is a bias in favor of independent non-executive directors. In the case of Banca Cívica, the fact that the bank is the result of a merger between four cajas may explain the high concentration of proprietary directors.

The only proprietary director on the board of Santander, Javier Botin-Sanz Sautuola y 0'Shea, owns $0.114 \%$ of the share capital and represents more than $1.5 \%$ of the shareholders. Recommendation 12 of the Unified Code recognizes that the presence of proprietary directors is justified where there are no significant shareholders, as defined by law, but the absolute value of the equity represented is high.

\section{Board committees}

We found eight different types of board committee: executive, audit, appointments and remuneration, risk, strategy, corporate governance, corporate social responsibility, international, and technology, productivity and quality.

Only three are common to all the banks in our sample, namely, the executive committee, the audit committee, and the appointments and remuneration committee.

The distribution of executive directors, proprietary directors and independent directors in the four most common types of committee is shown below:

\section{Figure 5}

Distribution of directors by committee type

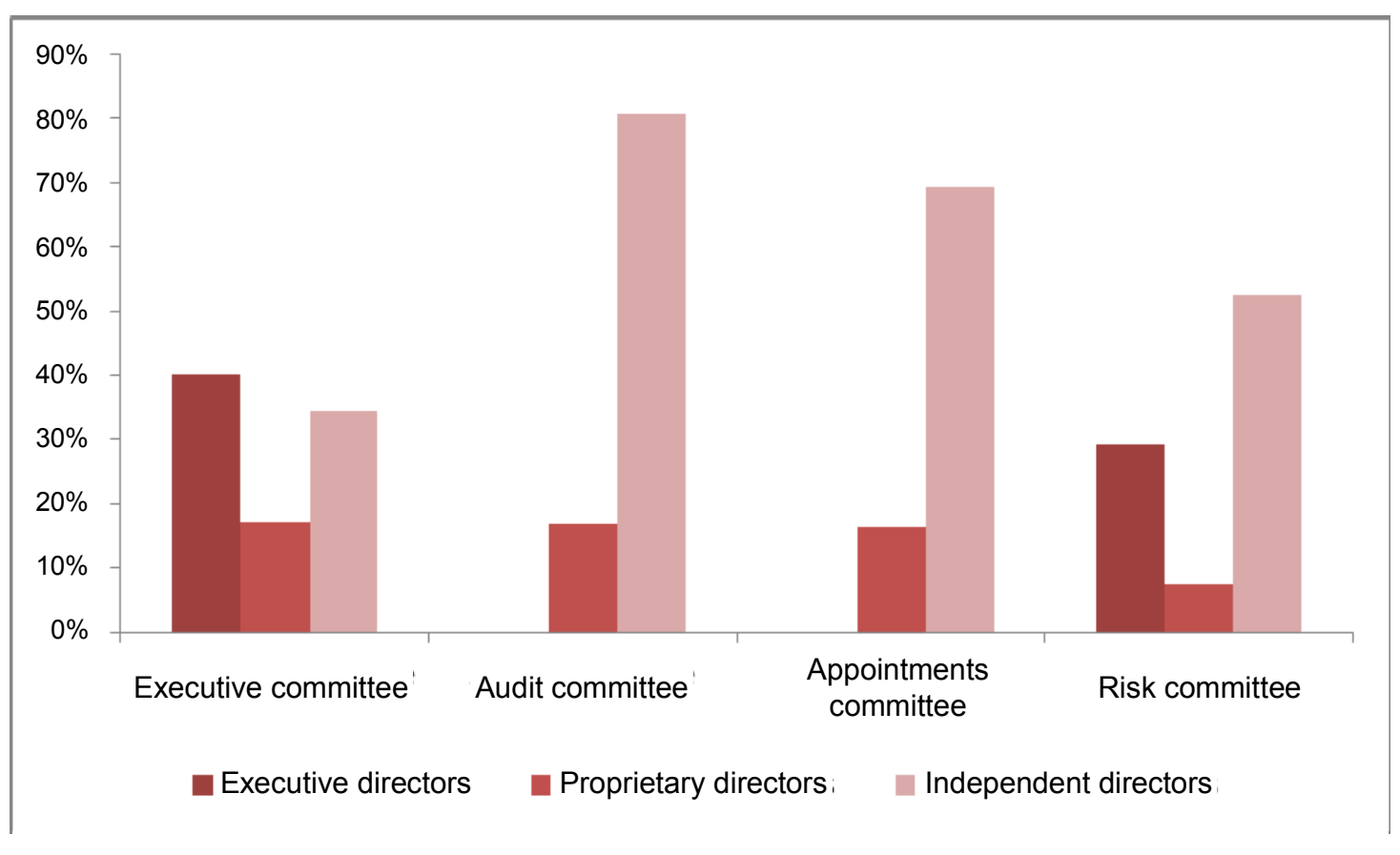

Source: compiled by the author based on data from IAGC.

Following the recommendations of the Unified Code, there are no executive directors on the audit and appointments committees. 
If we compare these results with the CNMV's annual report on corporate governance in Ibex 35 companies, we find that certain patterns are repeated. In Ibex 35 companies, the executive committee has an average of 32\% of executive directors, 34\% of proprietary directors and 31\% of independents. The audit committee is made up of $2 \%$ of executive directors, $32 \%$ of proprietary directors and $62 \%$ of independents. Lastly, the appointments and remuneration committee is made up of 3\% of executives, 32\% of proprietary directors and $60 \%$ of independents.

\section{Director's remuneration}

The CNMV provides aggregate data on the remuneration of the directors of Ibex 35 companies. The following table shows the total remuneration, the distribution of remuneration by category of director, and the percentage of fixed and variable remuneration and per diems for the banks in the Ibex 35: 


\section{Table 11}

Aggregate directors' remuneration

\begin{tabular}{|c|c|c|c|c|c|c|c|c|c|}
\hline & \multirow{2}{*}{$\begin{array}{c}\text { Total directors' remuneration } \\
\text { (thousands of euros) }\end{array}$} & \multicolumn{4}{|c|}{ Distribution by type of remuneration (\%) } & \multicolumn{4}{|c|}{ Distribution by type of director (\%) } \\
\hline & & Fixed & Variable & Per diems & Other & Executive & Proprietary & Independent & Other \\
\hline Santander & 34,130 & 31.5 & 34.9 & 4.2 & 29.4 & 86.4 & 0.4 & 8.9 & 4.3 \\
\hline BBVA & 12,989 & 50.3 & 43.7 & 0.0 & 6.0 & 68.4 & 0.0 & 31.6 & 0.0 \\
\hline Banesto & 9,197 & 33.6 & 48.9 & 2.1 & 15.4 & 90.2 & 0.9 & 7.7 & 1.2 \\
\hline B. Sabadell & 6,163 & 35.8 & 27.5 & 0.0 & 36.7 & 75.3 & 3.8 & 15.6 & 5.4 \\
\hline CaixaBank & 4,428 & 100.0 & 0.0 & 0.0 & 0.0 & 31.1 & 52.3 & 13.6 & 3.0 \\
\hline Bankinter & 4,137 & 46.2 & 9.2 & 20.7 & 23.9 & 70.9 & 5.3 & 18.7 & 5.1 \\
\hline B. Popular & 1,819 & 100.0 & 0.0 & 0.0 & 0.0 & 100.0 & 0.0 & 0.0 & 0.0 \\
\hline Average Ibex 35 & 7,169 & 43.7 & 26.1 & 12.8 & 17.4 & 63.2 & 16.8 & 17.2 & 2.9 \\
\hline
\end{tabular}

Source: compiled by the author based on data from the CNMV. 


\section{Factor analysis and cluster analysis}

In this section we aim to use the data for the various banks to derive some statistics. First, we have chosen certain variables that define the ownership structure and the board structure of all the banks in our sample. To these data we have applied factor analysis and cluster analysis.

Factor analysis serves to reduce the number of variables by finding homogeneous groups of variables. In our case, three factors explain almost $90 \%$ of the variability. The interpretation is as explained below.

High scores in the first factor indicate banks with a high free float, a marked presence of institutional investors, and high capitalization. Conversely, low scores in this factor indicate banks with high shareholder concentration and a marked presence of proprietary shareholders.

The second factor indicates board size, in terms of number of directors. A negative score in this factor may indicate board independence, measured by the proportion of independent directors.

The third factor shows the executive nature of the board, that is, the proportion of executive directors.

In the space of the new variables, each bank is referenced as shown below:

\section{Figure 6}

Banks in the space of the three chosen factors

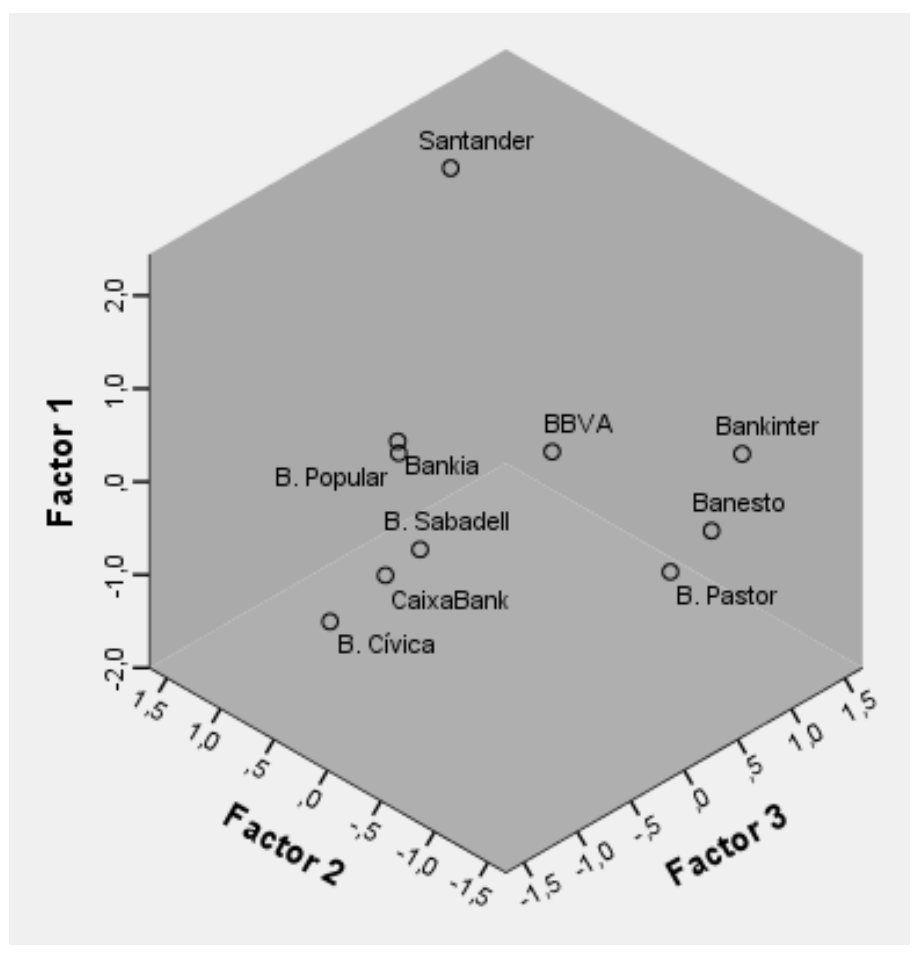

Source: compiled by the author.

To simplify the analysis we shall study the charts resulting from projecting the banks on the axes. 
Representing factor 1 compared to factor 2, we see that both Santander and BBVA are highly capitalized, with a high free float and a strong presence of institutional investors, well above the average for Spanish banks. Santander, however, has a much larger board than BBVA, which means that it scores higher in the second factor.

As regards the second factor, the banks with a larger-than-average board are, from largest to smallest: Santander, Bankia, Banco Popular, CaixaBank and Banca Cívica.

CaixaBank and Banca Cívica, in contrast, stand out for their high shareholder concentration and high proportion of proprietary directors.

Looking at the representation of factor 2 compared to factor 3, we can conclude that the banks with the smallest, most "executive" boards are Bankinter, Banesto and Banco Pastor. It should be noted that although Santander itself has an enormous board, its subsidiary, Banesto, does not, nor does Bankinter, the other bank in which the Botin family has a significant interest (through Cartival, S.A.).

\section{Figure 7}

Projections of the banks on the axes
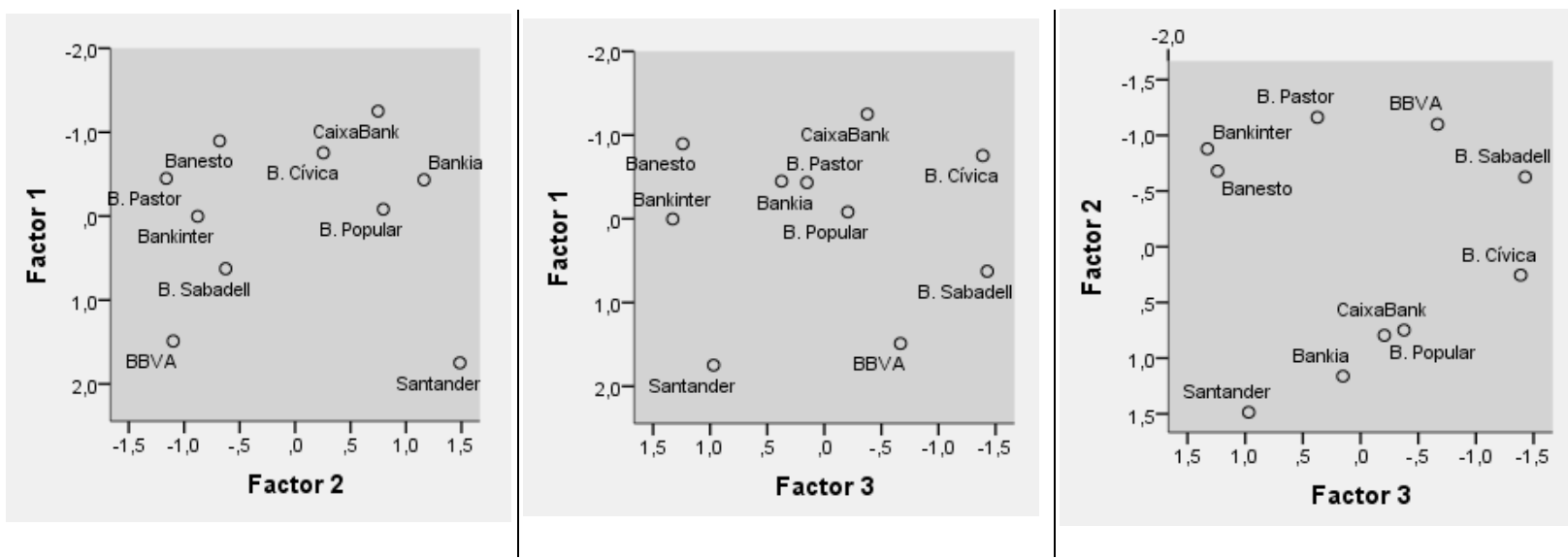

Source: compiled by the author. 
A widely used technique for grouping individuals in distinct, homogeneous classes is cluster analysis. We have chosen a set of variables characteristic of the banks' ownership structure and board structure, so as to produce a dendogram:

\section{Figure 8}

Dendogram

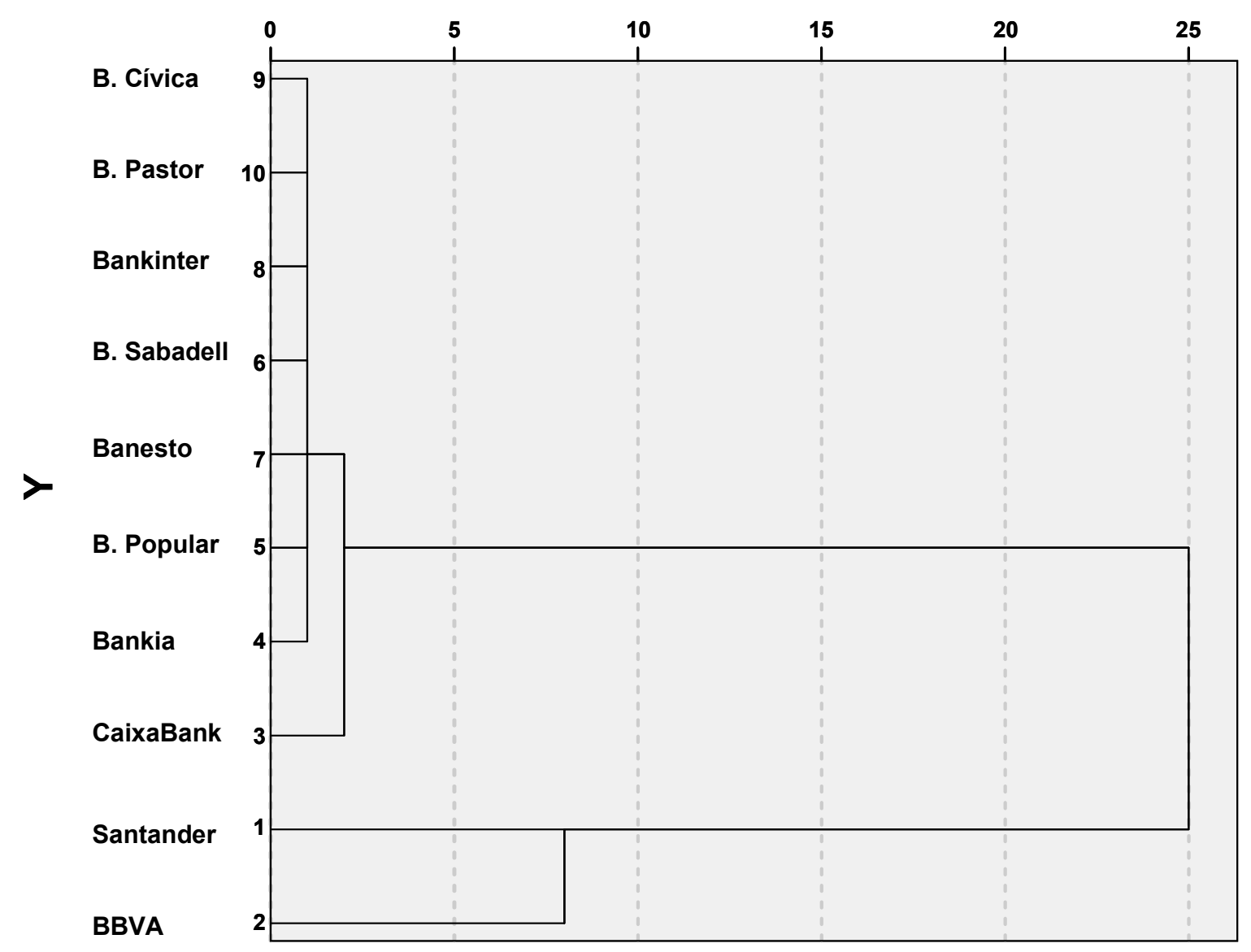

Source: compiled by the author.

Our conclusions are as follows: we can distinguish two large groups of banks, namely, Santander and BBVA, on the one hand, and the rest, from CaixaBank to Banco Pastor, on the other.

Refining our analysis, we distinguish four groups: Santander; BBVA; CaixaBank; and the rest, from Bankia to Banco Pastor. Note that the dissimilarity between the first two groups and the last two is considerable compared to the dissimilarity between the third and fourth group. That is to say, CaixaBank is closer to the group made up of all the remaining banks, from Bankia to Banco Pastor, than it is to the group of the two large banks. 


\section{Conclusions}

Spanish laws and regulations on corporate governance operate within the framework of European laws and regulations and are based on the circulars issued by the Banco de España and the Recommendations of the Unified Code (2006).

In this study we have situated Spanish banks within the overall domain of corporate governance. Taking the ten largest banks by market capitalization, we have drawn a map, on which we have situated the banks according to their ownership and governance.

Although general models of governance based on geographical criteria (United States, British and European models) do exist, they are not exactly applicable to Spanish banks.

On the one hand, Banco Santander and BBVA are closer in some respects to the United States or British conception of governance, with low shareholder concentration, high free float and a large presence of institutional investors. The boards of these banks have more independent directors than the average and the proportion of proprietary directors is small. As regards total directors' remuneration, it is worth noting that the figures for Santander and BBVA exceed the average for Ibex 35 companies by $400 \%$ and 180\%, respectively.

A historical exception is Banco Popular, where a high percentage of the owners are represented directly on the board, and which has recently acquired Banco Pastor. Also, the salary of the chairman and two senior managers account for $80 \%$ of the total directors' remuneration, amounting to 1.8 million euros. This is an example of transparency.

Among the banks resulting from mergers between cajas, CaixaBank is the exception. It has been led by the same management team for more than 30 years, giving it solidity, solvency and a sound reputation, besides complying with the rules of good governance. It is a model of professional management, supported by structured corporate governance. The only other bank with an equal concentration of power in the hands of the CEO is Bankia.

The remaining Spanish banks follow an eminently European model of corporate governance, with more concentrated ownership structures. Three of them (CaixaBank, Bankia and Banca Cívica) are owned mainly by cajas, the latter two being the result of mergers among cajas. The impact of their new shareholder structure on governance and management will not become apparent for another few years.

Special mention should be given to Banesto, controlled mainly by Santander, on account of its relatively small free float, less than $10 \%$, and the fact that its chairman, Antonio Basagoiti, representing the parent company, is a proprietary director.

The fact is that the banks that are currently in the best position have achieved these results with quite different business strategies and different styles of management and governance. Those that have had high quality professional management have taken the philosophy of corporate governance to heart. In other cases, this remains a requirement, even though it may be used for image purposes. A touchstone in all cases is succession in the position of chairman. 


\section{References}

Canals, J. (1996), Bancos universales y diversificación empresaria, Alianza Editorial.

National Securities Market Commission (2006), Unified Code on Good Corporate Governance.

National Securities Market Commission (2011), Informe anual de gobierno corporativo de las compañias del IBEX 35: Ejercicio 2010.

Basel Committee on Banking Supervision (2006), Enhancing corporate governance for banking organisations.

Crespí, R. and M. A. García-Cestona (2004), El gobierno de las entidades bancarias: Su evolución y el caso de las cajas de ahorros, Papeles de Economía Española, p. 101.

Crespí, R., M. A. García-Cestona and V. Salas (2004), Governance mechanisms in Spanish banks. Does ownership matter? Journal of Banking \& Finance, 28 (10), pp. 2311-2330.

Crespí, R. and B. Pascual (2009), Las prácticas de gobierno corporativo de las entidades bancarias cotizadas en españa 2004-2007. Análisis comparado con el mercado continuo, Revista de Estabilidad Financiera, p. 16.

Fainé, I. (2005), La evolución del sistema bancario español desde la perspectiva de los fondos de garantía de depósitos, Revista de Estabilidad Financiera, p. 8.

Fundación de Estudios Financieros (2011), Observatorio de gobierno corporativo 2010, Papeles de la Fundación.

Herrero, J. (2006), La responsabilidad de los administradores y directivos de las entidades de crédito, Revista de Estabilidad Financiera, p. 11.

Macey, J. R. and M. 0'Hara (2003), The corporate governance of banks, Economic Policy Review, 9 (1), p. 91.

Ricart, J., J. Álvarez and J. Gifra (2005), Los accionistas y el gobierno de la empresa, Ediciones Deusto.

Salas Fumás, V. (2002), El gobierno de la empresa, Fundación La Caixa.

Salas Fumás, V. (2003), El gobierno de la empresa bancaria desde la regulación, Revista de Estabilidad Financiera, p. 5.

Shleifer, A. and R. W. Vishny (1997), A survey of corporate governance, Journal of Finance, 52 (2), pp. 737-783.

Tricker, B. (2008), Corporate governance, Oxford University Press. 